\title{
RED FLAGS AND FRAUD PREVENTION ON RURAL BANKS
}

\author{
Ni Wayan Rustiarini ${ }^{1}$ \\ Ni Nyoman Ayu Suryandari ${ }^{2}$ \\ I Kadek Satria Nova ${ }^{3}$
}

\begin{abstract}
This paper identifies the effectiveness of the red flags in detecting fraudulent financial statements, as well as preventive measures appropriate to implemented in Bank Perkreditan Rakyat (BPR). We use field survey convering the whole BPR in Province Bali, covering 60 indicators provided to 101 internal auditors from 86 BPR. The result shows that the highest dimensions within the Fraud Diamond are capability. Efforts to prevent the fraud would be the culture of honesty and high ethics, evaluating anti-fraud process and control, and developing an appropriate oversight process.
\end{abstract}

Keywords: financial risk, liquidation, corporate governance, audit JEL Classification: G32, G33, G34, M420 


\section{PENDAHULUAN}

Bank Perkreditan Rakyat (BPR) memiliki peranan yang besar dalam perekonomian masyarakat khususnya memberikan pembiayaan bagi Usaha Mikro, Kecil dan Menengah (UMKM). Salah satu kebijakan yang dicanangkan BPR untuk mendukung sektor UMKM dalam mengembangkan usahanya adalah dengan menyalurkan modal usaha melalui kredit usaha rakyat yang memiliki plafon tinggi dan bunga rendah. Pada satu sisi, kebijakan tersebut menjadi suatu tantangan bisnis, namun pada sisi lain berpotensi menimbulkan kecurangan (fraud) apabila tidak diimbangi dengan integritas dan kompetensi sumber daya manusia yang tinggi dalam mengimplementasikan kebijakan. Bank Indonesia mencatat bahwa hampir tujuh puluh persen likuidasi pada BPR disebabkan kasus kecurangan perbankan yang dilakukan oleh pengelola BPR seperti direksi, komisaris, maupun pemilik BPR (finansial.bisnis.com, 2016).

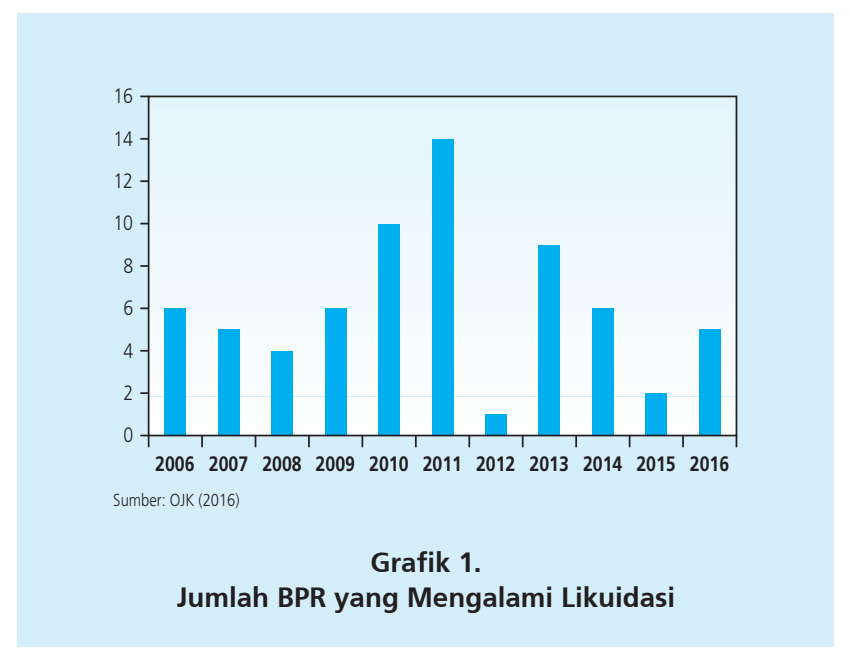

Selama kurun waktu 2006-2016, Lembaga Penjamin Simpanan telah melikuidasi 70 BPR dan 1 (satu) bank umum. Terdapat beberapa faktor yang menyebabkan pencabutan izin usaha BPR, namun Otoritas Jasa Keuangan (OJK) maupun Perhimpunan Bank Perkreditan Rakyat Indonesia (Perbarindo) menyatakan bahwa pencabutan izin bukan dikarenakan ketidakmampuan BPR tersebut dalam berkompetisi, melainkan karena kecurangan yang dilakukan pengurus ataupun pemilik bank mikro tersebut. Maraknya fenomena penutupan BPR kembali terjadi pada 2016 dimana OJK menutup lima BPR dalam kurun waktu enam bulan. Pada Januari 2016, OJK melikuidasi BPR Mitra Bunda Mandiri dari Sumatera Barat dan BPR Agra Arthaka Mulya dari Yogyakarta. Tiga bulan selanjutnya, OJK kembali melikuidasi tiga BPR lainnya yaitu BPR Dana Niaga Mandiri dari Sulawesi Selatan, BPR Syariah Al Hidayah, Jawa Timur, dan BPR Mustika Utama Kolaka dari Sulawesi Tenggara (infobanknews.com, 2016). 
Berdasarkan catatan OJK, tindak pidana perbankan lebih sering terjadi di BPR sehingga delapan puluh persen tindakan ini menyebabkan BPR tidak dapat beroperasi kembali (finance. detik.com, 2016). Banyaknya jumlah BPR yang beroperasi menyebabkan pengawasan BPR lebih sulit dan tidak simultan sebagaimana diterapkan pada bank-bank umum. Tidaklah mengherankan apabila potensi kecurangan pada BPR lebih tinggi dibandingkan bank umum. Sistem pengawasan yang lebih ketat pada bank umum menyebabkan kecurangan lebih mudah terdeteksi sehingga dapat diselesaikan secara internal dan tidak merugikan nasabah. Bercermin pada fenomena tersebut, BPR perlu memiliki sistem pengendalian internal BPR yang andal.

Meskipun kasus kecurangan yang terjadi pada BPR jauh lebih banyak dibandingkan pada bank umum, namun sampai saat ini pemerintah belum mengeluarkan peraturan yang mengharuskan BPR untuk memiliki strategi anti fraud. Untuk mengurangi peluang terjadinya penyimpangan ketentuan perbankan yang diduga fraud, OJK mengeluarkan Peraturan No 4/ POJK.03/2015 tentang Penerapan Tata Kelola bagi BPR yang berlaku sejak 31 Maret 2015. Regulasi tersebut menegaskan kewajiban BPR untuk melaksanakan prinsip-prinsip tata kelola dalam setiap kegiatan usaha pada seluruh tingkatan atau jenjang organisasi. Salah satu bentuk penerapan tata kelola yang sehat adalah dengan mengefektifkan fungsi audit intern sebagai bagian dari Sistem Pengendalian Intern (SPI) BPR. Surat Edaran OJK No 7/SEOJK.03/2016 tentang Standar Pelaksanaan Fungsi Audit Intern BPR menyatakan bahwa dalam melakukan pengawasan operasional yang mencakup perencanaan, pelaksanaan, dan pemantauan hasil audit, Direktur Utama dan Dewan Komisaris dibantu oleh Satuan Kerja Audit Intern (SKAI) atau Pejabat Eksekutif (PE) Audit Intern.

Tugas pendeteksian kecurangan bukanlah merupakan tugas yang mudah. SKAl atau PE Audit Intern memerlukan indikator atau tanda (red flags) yang dapat membantu dalam memfokuskan kinerja ketika melakukan pemeriksaan laporan keuangan. Red flags merupakan gejala potensial yang mengindikasikan risiko lebih tinggi atas suatu salah saji yang disengaja dalam laporan keuangan. Meskipun red flags dianggap sebagai alarm peringatan dini (early warning signal) yang dapat mengurangi risiko tidak terdeteksinya kecurangan, namun tetap diperlukan penyelidikan lanjutan yang lebih mendalam untuk mendapatkan hasil audit yang akurat. Berdasarkan konsep The Fraud Triangle, Statement on Auditing Standard No 99 mewajibkan auditor eksternal menggunakan 42 red flags saat mendeteksi kecurangan laporan keuangan. Beberapa penelitian sebelumnya telah dilakukan untuk mengidentifikasi efektivitas pengunaan red flags berbasis The Fraud Triangle dalam mendeteksi kecurangan (Albrecht dan Romney, 1986; Pincus, 1989; Heiman-Hoffman et al., 1996; Moyes et al., 2006; Omar, 2011; Rustiarini dan Novitasari, 2014). Penelitian ini bermaksud mengembangkan hasil-hasil penelitian sebelumnya dengan menggunakan konsep baru yaitu The Fraud Diamond.

Tujuan penelitian ini untuk mengidentifikasi efektivitas red flags dalam pendeteksian kecurangan laporan keuangan perbankan, khususnya BPR. SKAl atau PE Audit Intern BPR juga diminta untuk mengidentifikasi langkah-langkah pencegahan kecurangan yang diyakini tepat 
untuk diimplementasikan pada BPR. Dua hal ini penting dan menarik untuk diteliti mengingat kecurangan yang terjadi pada sektor perbankan bersifat sistemik, yaitu dampaknya dapat meluas ke bank lain yang sejenis atau bahkan ke sistem perbankan secara keseluruhan. Kecurangan yang terjadi pada beberapa BPR tentunya berdampak negatif pada industri BPR, dan apabila tidak segera diatasi dapat mengurangi kepercayaan masyarakat terhadap bank ini. Dengan demikian diperlukan langkah-langkah proaktif dari SKAI atau PE Audit Intern untuk menentukan indikator maupun upaya pencegahan dan pendeteksian kecurangan akuntansi.

Penelitian ini menggunakan survei kuesioner pada auditor internal SKAI atau PE Audit Intern selaku fungsi yang bertanggungjawab melakukan pengawasan internal pada sistem pengendalian intern BPR. Studi ini memberikan kontribusi teoritis untuk melengkapi hasil-hasil penelitian sebelumnya yang menggunakan konsep The Fraud Triangle. Landasan teori berbeda digunakan pada penelitian ini yaitu The Fraud Diamond yang mempertimbangkan semua faktor individual pada seseorang sebagai pelaku kecurangan. Hasil penelitian ini diharapkan menjadi masukan ketika memformulasikan kebijakan atau strategi anti fraud pada BPR, sebagaimana telah diterapkan pada bank umum. Sebelumnya Bank Indonesia mengeluarkan Surat Edaran No.13/28/DPNP Tahun 2011 tentang Penerapan Strategi Anti Fraud bagi Bank Umum yang mewajibkan setiap bank umum memiliki strategi anti fraud yang komprehensif dan rinci untuk memperkuat SPI bank tersebut. Namun sampai saat ini belum ada regulasi sejenis yang dikeluarkan pemerintah untuk BPR padahal kasus kecurangan lebih sering terjadi pada BPR dibandingkan bank umum. Dengan demikian penelitian ini penting dan menarik dilakukan untuk dapat merumuskan indikator-indikator pendeteksi kecurangan dan langkah-langkah yang diperlukan untuk mencegah terjadinya kecurangan.

Bagian pertama paper ini merupakan pendahuluan yang menguraikan latar belakang dan tujuan penelitian. Bagian kedua mengulas teori yang berkaitan dengan model, terutama The Fraud Diamond sebagai pondasi dalam penentuan indikator-indikator pendeteksian fraud. Bagian ketiga mengulas metodologi, dan bagian keempat dari paper ini menyajikan hasil dan analisis. Kesimpulan dan saran disajikan pada bagian terakhir.

\section{TEORI}

\subsection{The Fraud Diamond}

Teori yang digunakan sebagai landasan dalam penelitian ini adalah Theory of Fraud Diamond. Sebelum konsep ini diperkenalkan secara luas, Asosiasi Certified Fraud Examiners menggunakan model The Fraud Triangle yang dikemukakan Cressey $(1950,1953)$ sebagai pondasi awal dalam berbagai penelitian mengenai kecurangan. Konsep fraud triangle menekankan tiga elemen penyebab terjadinya kecurangan yaitu tekanan (pressure) atau insentif (incentive), kesempatan (opportunity), dan rasionalisasi (rationalization). The Fraud Diamond yang diperkenalkan oleh Wolfe dan Hermanson (2004) menambahkan kemampuan (capability) sebagai elemen keempat. 
Dasar pemikiran yang melandasi konsep ini bahwa kecurangan tidak terjadi tanpa orang yang tepat, posisi yang tepat, dan tentunya harus memiliki kemampuan yang tepat.

Elemen pertama, tekanan merupakan kondisi dimana seseorang menerima tuntutan, baik keuangan maupun non keuangan sehingga lebih rentan untuk melakukan kecurangan (Choo dan Tan, 2007). Dalam hal keuangan, tekanan terjadi ketika manajemen membutuhkan uang untuk memenuhi kebutuhan pribadi seperti tekanan ekonomi dalam keluarga atau gaya hidup (Rustendi, 2009). Tekanan non keuangan terjadi ketika target keuangan melampaui kemampuan manajemen, adanya kompensasi, insentif, atau jenjang karir yang tidak sesuai dengan harapan, maupun kegagalan hubungan kerja antara karyawan dan perusahaan (Moeller, 2009) sehingga mengubah perilaku untuk melakukan kecurangan.

Elemen kedua, kesempatan adalah tersedianya peluang bagi seseorang untuk melakukan kecurangan. Beberapa kondisi yang menciptakan peluang tersebut seperti lemahnya sistem pengendalian internal, ketidakdisplinan dalam menjalankan prosedur, kesulitan mengakses informasi, serta tidak adanya mekanisme audit. Adanya tata kelola perusahaan yang buruk dan terbatasnya regulasi juga memberikan kesempatan untuk melaksanakan aksi yang merugikan perusahaan. Bahkan adanya tekanan dari pemerintah kepada perusahaan juga dapat mendorong pihak manajemen perusahaan untuk aktif mencari peluang dan cara untuk melakukan kecurangan (Choo dan Tan, 2007). Elemen ketiga yaitu rasionalisasi, merupakan sikap atau nilai-nilai etis yang digunakan seseorang untuk menjustifikasi perbuatan yang dilakukan, atau sebagai salah satu cara yang digunakan manajer untuk membenarkan tindakan kecurangan bagi diri sendiri (Choo dan Tan, 2007). Rasionalisasi sering digunakan pada kecurangan yang bersifat situasional.

Elemen keempat adalah kemampuan, yang diartikan sebagai sifat individu yang mendorong seseorang untuk mencari kesempatan dan memanfaatkannya untuk melakukan kecurangan. Terdapat enam hal yang memungkinkan seseorang untuk melakukan kecurangan yaitu: (1) memiliki kedudukan penting atau menempati posisi tertentu yang tidak tersedia bagi orang lain, (2) memiliki kapasitas lebih seperti cerdas dan kreatif untuk memahami dan mengeksploitasi kelemahan sistem akuntansi dan pengendalian internal perusahaan, (3) memiliki keyakinan bahwa kecurangan yang dilakukan tidak akan terdeteksi, ataupun jika tertangkap akan dengan mudah keluar dari perusahaan, (4) memiliki kemampuan untuk melakukan pemaksaan, yaitu dapat mempengaruhi orang lain untuk membantu atau menyembunyikan kecurangan yang terjadi, (5) memiliki kemampuan untuk berbohong atau mengalihkan keadaan, (6) memiliki kemampuan untuk mengelola stres akibat menyembunyikan kecurangan atau ketika melakukan tindakan yang buruk (Hay, 2013). Wolfe dan Hermanson (2004) menyajikan model The Fraud Diamond dalam Diagram 1. 


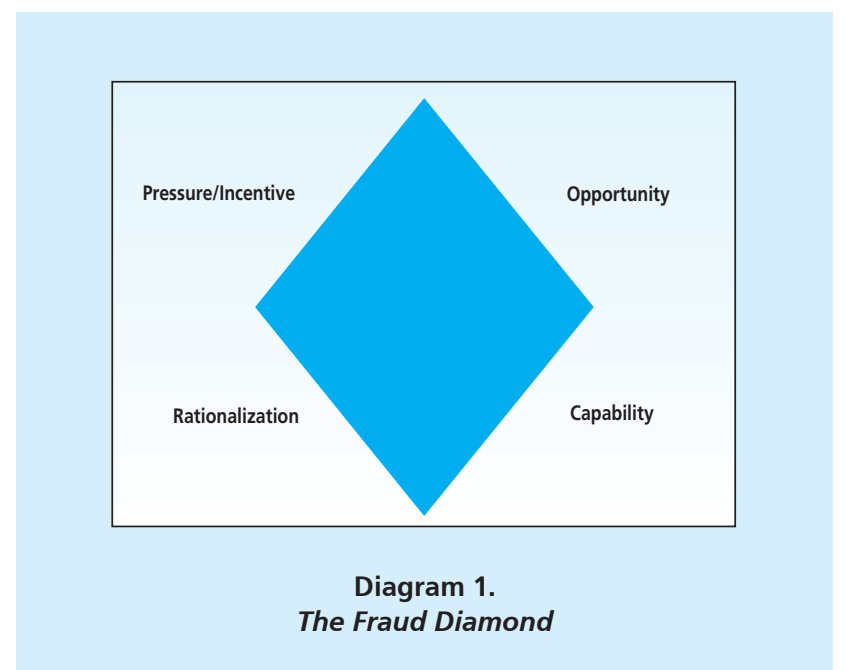

\subsection{Kecurangan (Fraud)}

Istilah kecurangan tidak terlepas dari perkembangan dunia bisnis. Isu-isu suap, penggelapan uang, pencucian uang, maupun pencurian produk hanya segelintir contoh dari sejumlah kasus yang pernah terjadi. Statement of Auditing Standards No.99 mendefinisikan fraud sebagai tindakan kesengajaan untuk menghasilkan salah saji material dalam laporan keuangan. Tuanakotta (2010) menyatakan kecurangan sebagai tindakan sengaja untuk melakukan atau tidak melakukan sesuatu yang semestinya sehingga perusahaan menerbitkan laporan keuangan yang dapat menyesatkan pemakai secara material. Kecurangan dapat dikelompokkan dalam tiga bentuk yaitu penyelewengan aset (asset misappropriation), kecurangan akuntansi atau kecurangan laporan keuangan (financial statement fraud), dan korupsi (corruption).

Dalam ketentuan dunia perbankan, definisi fraud diatur dalam Surat Edaran No. 13/28/ DPNP Tahun 2011 mengenai Penerapan Strategi Anti Fraud bagi Bank Umum. Fraud dikatakan sebagai tindakan penyimpangan atau pembiaran yang sengaja dilakukan untuk mengelabui, menipu, atau memanipulasi Bank, nasabah, atau pihak lain yang terjadi di lingkungan Bank dan/atau menggunakan sarana Bank sehingga mengakibatkan Bank, nasabah, atau pihak lain menderita kerugian baik secara langsung maupun tidak langsung. Tiga kelompok perbuatan kecurangan yang sering terjadi dalam dunia perbankan adalah penyimpangan terkait dengan pemberian kredit (43\%), melakukan manipulasi (19.6\%), dan pemalsuan (18.6\%). Perbuatan tidak etis lainnya yang dapat dikategorikan sebagai kecurangan adalah penggelapan, penyalahgunaan wewenang, penyalahgunaan ATM dan PIN, serta penyalahgunaan dana nasabah (OJK, 2016). Jumlah pelaku yang diduga melakukan tindak pidana bank (tipibank) adalah pemegang saham sebanyak satu orang, direksi sebanyak tujuh orang, pejabat eksekutif sebanyak sepuluh orang, dan karyawan sebanyak satu orang. 
Terjadinya krisis ekonomi turut meningkatkan peluang terjadinya fraud di beberapa negara. Satu dari tiga perusahaan di seluruh dunia melaporkan diri sebagai korban kecurangan selama 12 bulan terakhir (Gillentine, 2009), serupa dengan hasil survei yang dilakukan oleh PricewaterhouseCoopers (PWC, 2009) yang melaporkan bahwa sebesar 30\% responden menyatakan pernah mengalami kecurangan. KPMG (2009) juga menemukan bahwa 65\% dari eksekutif perusahaan menyebutkan bahwa kecurangan merupakan risiko yang sering terjadi pada perusahaan mereka. Berkaitan dengan pelaku kecurangan, studi yang dilakukan Wolfe dan Hermanson (2004) mengungkapkan bahwa sebagian besar kecurangan dilakukan oleh orang dalam perusahaan. Fakta ini mempertegas hasil survei Ernst and Young yang menyimpulkan bahwa sebesar $82 \%$ responden menyatakan adanya keterlibatan pegawai dalam kecurangan, dan sebesar 28\% melibatkan manajemen (Wolfe dan Hermanson, 2004).

Kondisi ini tidak jauh berbeda dengan kasus kecurangan perbankan yang terjadi di Indonesia. Untuk tahun 2016 yang sedang berjalan ini, LPS telah melikuidasi lima BPR selama lima bulan pertama. Jumlah ini kemungkinan terus meningkat hingga tujuh sampai delapan BPR sampai akhir tahun (bisnis keuangan.kompas.com, 2016). Meskipun terdapat beberapa faktor penyebab pencabutan izin BPR tersebut, penyebab utama dilakukannya penutupan adalah kondisi internal BPR yang tidak sehat seperti praktik kecurangan. Pengurus BPR sering melupakan ketentuan prudential perbankan sehingga menggunakan dana masyarakat secara tidak bertanggungjawab. Penyalahgunaan wewenang oleh pengelola BPR ini memicu munculnya masalah lain seperti memiliki kinerja keuangan yang buruk. Fenomena ini semakin mempertegas bahwa sebagian besar kecurangan dilakukan oleh pihak internal pengelola seperti direksi, komisaris, dan pemilik BPR. Meskipun terdapat nasabah yang melakukan kecurangan, tentunya tidak bisa terlepas dari bantuan orang dalam perusahaan. Oleh karena itu diperlukan sistem pengendalian intern yang andal dan memadai.

\subsection{Indikator Kecurangan (Red Flags)}

Pekerjaan mendeteksi kecurangan bukanlah merupakan hal yang mudah bagi seorang auditor. Meskipun kasus kecurangan bukanlah merupakan suatu hal asing dalam dunia bisnis, namun seringkali pihak auditor baik internal maupun eksternal tidak mampu mengungkapkan kasus tersebut. Seringkali kecurangan dikemas sedemikian rupa sehingga auditor akan sulit untuk mendeteksi terjadinya salah saji. Association of Certified Fraud Examiners (ACFE, 2010) menyatakan bahwa auditor internal hanya mampu mendeteksi 13.7\% kasus kecurangan yang terjadi, sedangkan auditor eksternal memiliki angka yang lebih rendah yaitu sebesar $4.2 \%$ dari total kasus yang dilaporkan. Kondisi ini bertolakbelakang dengan hasil survei yang dilakukan dua kantor akuntan publik besar yaitu KPMG dan PricewaterhouseCooper di Malaysia tahun 2009 yang menunjukkan bahwa sesungguhnya sebelum kasus kecurangan keuangan terjadi, auditor dapat mendeteksi kecurangan melalui indikator-indikator (red flags). Namun auditor seringkali mengabaikan keberadaan red flags atau justru melakukan "pushed under the carpet" sesuai 
permintaan perusahaan yang menjadi korban kecurangan. Berbagai alasan yang digunakan untuk mengabaikan indikator tersebut seperti menjaga reputasi perusahaan, potensi pasar, dan motivasi kerja karyawan. Perusahaan juga menggunakan alasan "jumlah yang terlalu kecil untuk mempengaruhi perusahaan" (Omar dan Din, 2010). Dengan demikian auditor sengaja tidak mengungkapkan indikator-indikator kecurangan tersebut dalam laporan audit, atau tidak mendiskusikannya dengan manajemen perusahaan.

Groveman (1995) dalam artikelnya yang memfokuskan pada pendeteksian salah saji laporan keuangan mengungkapkan bahwa seringkali penyebab kegagalan audit adalah ketidaktepatan reaksi tim audit terhadap berbagai sinyal peringatan. Auditor harus memahami sinyal ini dan bertindak yang benar sesuai petunjuk yang diberikan sinyal tersebut. Adanya overstatement dalam pencatatan persediaan, penerapan prinsip akuntansi yang agresif, ketidaktepatan pengakuan pendapatan, cadangan kerugian yang tidak memadai, understatement dalam pencatatan biaya dan bebas, serta adanya transaksi tidak biasa dengan pihak terkait merupakan suatu indikator dari salah saji laporan keuangan. Sinyal utama lainnya bisa berupa struktur organisasi yang rumit, kerjasama atau joint venture yang tidak biasa, dan terjadinya pergantian auditor (Friedman, 1995). Tanda-tanda kecurangan tersebut dapat berupa ketidakjujuran manajer pada auditor, seringnya terjadi perselisihan antara manajer dan auditor, keinginan manajer untuk mencapai target ataupun keuntungan dari proyek yang ada, serta keinginan klien untuk mendapat persetujuan opinion shopping (Heiman-Hoffman et al., 1996).

Apabila indikator tersebut tampak ketika mengaudit laporan keuangan klien, maka auditor harus bersikap skeptis dan lebih menginvestigasi untuk memastikan kecurangan tersebut. Jika memungkinkan agar tidak sampai menyebabkan salah saji material dalam catatan keuangan. Apabila terdapat suatu hal yang patut dicurigai, indikator ini membantu auditor untuk memfokuskan kinerja dalam melakukan penaksiran risiko kecurangan.

\subsection{Efektivitas Indikator Kecurangan (Red Flags)}

Statement on Auditing Standard No 99 mewajibkan auditor eksternal menggunakan 42 red flags dalam mendeteksi kecurangan pelaporan keuangan (Moyes et al., 2006). Sesungguhnya setiap red flags memiliki tingkat efektivitas yang berbeda dalam mendeteksi kecurangan. Perbedaan penilaian tersebut disebabkan perbedaan persepsi (Apostolou et al., 2001; Moyes, 2007), karakteristik pribadi yang menilai (Robbins dan Judge, 2008), insentif (Messier et al., 2005), atau perbedaan kegiatan dan tanggung jawab yang berhubungan dengan pekerjaan (Gullkvist dan Jokipii, 2013). Bahkan individu yang berada dalam profesi yang sama yaitu auditor internal dan auditor eksternal pun memiliki persepsi yang berbeda atas efektivitas red flags.

Auditor internal biasanya termotivasi untuk mengidentifikasi penyebab terjadinya kecurangan dan memastikan adanya pengendalian intern yang efektif dalam perusahaan untuk mencegah terjadinya kecurangan (Norman et al., 2011). Manajemen harus memutuskan 
apakah akan mengembangkan sistem pengendalian tambahan untuk beberapa kondisi yang belum teratasi. Dalam hal ini manajemen perlu melakukan analisis biaya-manfaat dari risiko biaya pengendalian versus manfaat mitigasi atau pengurangan risiko tersebut (PwC, 2004). Auditor internal berusaha untuk mencegah hasil yang merugikan perusahaan sehingga mereka cenderung untuk memperhitungkan analisis biaya manfaat yang menguntungkan perusahaan. Satu hal penting yang perlu diingat bahwa sistem pengendalian internal tidak akan efektif untuk kecurangan yang dibuat oleh manajemen puncak karena mereka tidak akan membiarkan auditor internal untuk menyelidiki kecurangan yang dilakukan. Dalam kondisi ini, diperlukan peran dewan komisaris, komite audit, dan auditor eksternal.

Auditor eksternal berperan untuk mengungkapkan kecurangan yang terjadi karena rendahnya sistem pengendalian internal dan kecurangan yang dilakukan oleh manajemen puncak. Dalam menentukan efektivitas red flags, auditor memiliki pandangan yang berbeda dari sisi materialitas karena ditentukan oleh insentif yang berbeda (Messier et al., 2005), meskipun belum ada pedoman baku mengenai besarnya cut off yang menjadi ambang batas materialitas tersebut (Blokdijk et al., 2003). Auditor eksternal apakah akan melaporkan adanya perbedaan atau penyimpangan material, atau apakah keputusan suatu item tersebut bersifat material atau tidak, akan sangat tergantung pada penilaian risiko kecurangan.

Penelitian mengenai persepsi auditor eksternal dan auditor internal atas efektivitas red flags telah diuji menggunakan konsep The Fraud Triangle (Albrecht dan Romney, 1986; Pincus, 1989; Kaplan dan Reckers, 1995; Heiman-Hoffman et al., 1996; Weiseborn dan Norris, 1997; Moyes et al., 2006; Hegazy dan Kassem, 2010; Omar, 2011; Yang et al., 2009; Moyes dan Baker, 2009; Moyes et al., 2013; Gullkvist dan Jokipii, 2013; Rustiarini dan Novitasari, 2014), serta sebagai indikator dari risiko kecurangan manajemen (Coram et al., 2008; Liou, 2008). Temuan tersebut menunjukkan berbagai hasil yang berkaitan dengan pentingnya indikator dalam menilai risiko kecurangan.

Sebelum terjadinya kasus Enron, keberadaan red flags dalam melaksanakan pengauditan bukanlah merupakan hal yang penting, yang terlihat dari beberapa hasil penelitian sebelumnya. Albrecht dan Romney (1986) mengungkapkan bahwa red flags hanya digunakan ketika terjadi kecurangan, dan ketika kecurangan tidak terjadi maka red flags tidak akan bermanfaat. Pincus (1989) pun mengungkapkan bahwa indikator tersebut hanya berfungsi untuk melengkapi dan menyeragamkan metode audit, namun tidak membantu dalam memprediksi dan menilai risiko kecurangan, serta hanya berpengaruh pada pelaporan yang terbatas (Kaplan dan Reckers, 1995) Hasil yang serupa diungkapkan Weiseborn dan Norris (1997) yang menjelaskan bahwa penggunaan red flags tersebut tidak valid untuk mendeteksi kecurangan yang disebabkan oleh manajemen, namun lebih tepat digunakan untuk mendeteksi kecurangan non manajemen.

Hasil-hasil penelitian yang kontradiksi mulai bermunculan sejak terjadinya kasus Enron yang membuktikan pentingnya red flags dalam mendeteksi kecurangan. American Institute of Certified Public Accountant (2002) melaporkan bahwa sesungguhnya telah terdapat 16 red 
flags yang terlihat jelas sebelum runtuhnya Enron. Pernyataan ini seolah mengingatkan profesi auditor untuk tetap menggunakan daftar red flags dalam melakukan tugasnya. Pernyataan ini mendapat dukungan dari sebagian besar responden dalam penelitian Koornhof dan Plessis (2000) yang menyatakan bahwa red flags bermanfaat dalam menilai risiko kecurangan dan memberikan informasi awal tentang potensi terjadinya kecurangan. Beberapa peneliti lainnya (Hegazy dan Kassem, 2010; Moyes et al., 2006) juga mengklaim bahwa red flags efektif untuk digunakan dalam mendeteksi kecurangan. Konsisten dengan hasil penelitian sebelumnya, temuan Gullkvist dan Jokipii (2013) juga menunjukkan bahwa auditor internal merasakan pentingnya red flags terkait dengan mendeteksi penyalahgunaan aset dari orang-orang yang terkait dengan kecurangan pelaporan keuangan.

Seiring berjalannya waktu, para regulator dan akademisi yang memfokuskan pada metode pendeteksian dan pencegahan kecurangan telah mengembangkan satu indikator kecurangan yang baru. Mengacu pada perkembangan keilmuan, penelitian ini mengembangkan hasilhasil penelitian sebelumnya menggunakan konsep baru yaitu The Fraud Diamond. Konsep ini digunakan karena sejatinya untuk melakukan suatu kecurangan, tidaklah cukup jika hanya didasarkan pada tekanan, kesempatan atau rasionalisasi. Hal terpenting yang harus dimiliki oleh aktor kecurangan adalah kemampuan yang cukup untuk menggabungkan ketiga faktor tersebut menjadi suatu tindakan yang nyata.

\subsection{Sistem Pengendalian Intern BPR}

Surat Edaran OJK No 7/SEOJK.03/2016 tentang Standar Pelaksanaan Fungsi Audit Intern BPR menyatakan bahwa sistem pengendalian intern merupakan mekanisme pengendalian yang dibangun untuk menjaga dan mengamankan harta kekayaan BPR, mengurangi dampak kerugian termasuk kecurangan, meningkatkan efektivitas organisasi, serta diharapkan dapat meningkatkan efisiensi biaya. Fungsi audit intern merupakan bagian dari sistem pengendalian intern dan merupakan segala bentuk kegiatan yang berhubungan dengan audit dan pelaporan hasil audit mengenai terselenggaranya sistem pengendalian secara terkoordinasi dalam setiap tingkatan manajemen. Ruang lingkup pengendalian intern BPR meliputi aspek-aspek yang mampu menjamin keamanan dana yang disimpan oleh masyarakat dan pihak ketiga lainnya. Untuk mewujudkan transparansi dan kejelasan, diperlukan audit intern untuk mendukung terciptanya sistem pengendalian intern yang efektif.

Pelaksana Fungsi Audit Intern adalah Satuan Kerja Audit Intern (SKAI) atau Pejabat Eksekutif (PE) Audit Intern yang membantu tugas Direktur Utama dan Dewan Komisaris dalam melakukan pengawasan operasional BPR yang mencakup perencanaan, pelaksanaan, dan pemantauan hasil audit. SKAl atau PE Audit Intern membuat analisis dan penilaian di bidang keuangan, akuntansi, operasional, dan kegiatan lainnya paling sedikit dengan cara pemeriksaan langsung dan analisis dokumen, serta memberikan saran perbaikan dan informasi yang objektif tentang kegiatan yang diperiksa pada semua tingkatan manajemen. SKAI atau PE Audit Intern 
juga harus mampu mengidentifikasi segala kemungkinan untuk memperbaiki dan meningkatkan efisiensi penggunaan sumber daya dan dana.

Struktur organisasi fungsi audit intern dibentuk sesuai dengan jumlah modal inti sebagaimana dimaksud dalam Pasal 59 Peraturan OJK tentang Tata Kelola BPRyaitu:

1) BPR dengan modal inti paling sedikit Rp 50.000.000.000,00 (lima puluh milyar rupiah) wajib membentuk Satuan Kerja Audit Intern (SKAI); atau

2) BPR dengan modal inti kurang dari Rp 50.000.000.000,00 (lima puluh milyar rupiah) wajib menunjuk 1 (satu) orang PE Audit Intern.

Selain berbagai regulasi tersebut, pada triwulan I-2016, telah diterbitkan satu kajian mengenai Pengawasan BPR Berdasarkan Risiko (Risk Based Supervision-RBS). Kajian ini dibuat untuk mengembangkan metode pengawasan BPR yang efektif dan efisien sehingga tumbuh dengan baik dan memberikan kontribusi terhadap perekonomian rakyat, terutama di wilayah regional tempat BPR tersebut berada. Dalam rangka peningkatan Capacity Building Pengawas BPR, pada triwulan I-2016 juga telah dilakukan sosialisasi mengenai perubahan sistem pengawasan BPR dari pengawasan BPR berdasarkan kepatuhan (compliance based supervision) menjadi berdasarkan risiko (risk based supervision). Kegiatan ini merupakan langkah awal untuk mengenalkan pengawasan BPR berdasarkan risiko kepada para pengawas BPR mengingat perubahan ini memerlukan perubahan paradigma pengawas dari compliance based menjadi risk based, serta memperkenalkan tahapan-tahapan yang nantinya wajib dilakukan pengawas dalam menerapkan siklus pengawasan berdasarkan risiko (OJK, 2016).

\section{METODOLOGI}

Penelitian ini merupakan penelitian survei yang dilakukan pada seluruh BPR yang ada di Provinsi Bali. Terdapat beberapa pertimbangan yang melandasi pemilihan lokasi penelitian. Pertama, OJK Regional VIII Bali-Nusa Tenggara mencatat bahwa secara umum BPR di Provinsi Bali memiliki kinerja yang baik, khususnya untuk periode Desember 2014-Oktober 2015. Namun tidak dipungkiri masih terdapat beberapa kelemahan yang harus diperbaiki seperti penguatan permodalan BPR, peningkatan kualitas sumber daya manusia secara berkesinambungan, serta penerapan tata kelola BPR yang baik (bali.bisnis com, 2016). Kedua, laporan Kajian Ekonomi dan Keuangan Regional Triwulan II 2016 yang dipublikasikan oleh Bank Indonesia menyajikan adanya kenaikan rasio Non Performing Loan (NPL) atau kredit macet untuk BPR di Provinsi Bali mencapai 4.75\%, bahkan menembus angka 5.75\% untuk September 2016 (Radar Bali, 2016). Angka ini melebihi batas NPL yang ditetapkan OJK yaitu sebesar 5\%. Kondisi ini disebabkan kenaikan harga yang sangat cepat pada sektor konstruksi, perdagangan, akomodasi, dan real estate di Bali, hingga menimbulkan kejenuhan harga. Terjadinya expectation gap ini menyebabkan investor yang berbisnis menggunakan kredit bank akan menunda pembayaran kreditnya (bali.tribunnews.com, 2016). Tidak jarang kasus kredit macet ini menjadi sumber 
terjadinya tipibank. Data OJK menunjukkan bahwa dari 26 kasus tipibank yang terjadi, sebesar 55\% disebabkan oleh kasus kredit (finance.detik.com, 2016).

Ketiga, kinerja BPR di Provinsi Bali berkaitan erat dengan keberadaan Lembaga Perkreditan Desa (LPD) selaku lembaga keuangan mikro yang terdapat di setiap desa adat di Bali. Dalam hal ini, jumlah LPD yang mencapai angka 1.466 menjadi kompetitor bagi BPR dalam menyalurkan kredit. Terlebih, persyaratan kredit di LPD lebih mudah, pencairan dana lebih cepat, dan memiliki fasilitas pemberian kredit tanpa agunan dengan nilai tertentu pada masyarakat yang berada pada desa adat tempat LPD tersebut beroperasional. Tingginya tingkat persaingan ini menyebabkan karyawan BPR cenderung mengabaikan prosedur dan ketentuan pemberian kredit untuk mengejar target semata (beritadewata.com, 2016). Beberapa tindakan fraud yang dilakukan petugas bank seperti over finance credit, pencatatan dokumen pendukung proposal kredit palsu, kecurangan lainnya yang dilakukan pihak debitur, pihak ketiga, maupun pihak bank sendiri (Radar Bali, 2016). Berbagai fenomena ini mendasari pemikiran pentingnya dilakukan penelitian pada BPR di Provinsi Bali.

Pengumpulan data menggunakan kuesioner untuk mengetahui persepsi karyawan SKAI atau PE Audit Intern atas efektivitas red flags dalam mendeteksi kecurangan laporan keuangan BPR, serta mengidentifikasi upaya yang diperlukan dalam pencegahan kecurangan. Mengingat peran yang dimandatkan kepada karyawan SKAI atau PE Audit Intern memiliki fungsi yang sama dengan auditor internal, maka untuk selanjutnya penelitian ini akan menggunakan istilah auditor internal untuk menggantikan istilah karyawan SKAI atau PE Audit Intern. Berdasarkan data yang diperoleh dari Perbarindo Bali untuk tahun 2016, terdapat 138 BPR yang tersebar pada 9 (sembilan) kabupaten dan kotamadya di Bali. Sebanyak 44 BPR belum memiliki auditor internal, namun ada juga beberapa BPR yang memiliki auditor internal dengan jumlah lebih dari satu orang. Terdapat 8 (delapan) BPR yang tidak ikut berpartisipasi dalam penelitian ini dengan alasan kesibukan rutin, menjalani pemeriksaan dari OJK, terdapat pergantian pimpinan, melakukan renovasi gedung, dan tidak diijinkan oleh pimpinan. Dengan demikian, terdapat 86 BPR yang berpartisipasi dalam penelitian ini. Periode pelaksanaan survei berkisar antara Juni 2016 sampai dengan September 2016. Adapun jumlah auditor internal yang bersedia untuk mengisi kuesioner adalah sebanyak 101 orang yang berasal dari 86 BPR. 


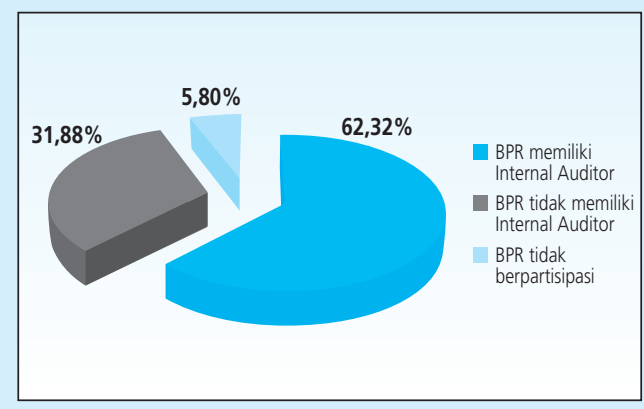

Grafik 2.

Tingkat Partisipasi BPR

Kuesioner yang digunakan dalam penelitian ini terdiri dari tiga bagian. Bagian pertama berisi pertanyaan mengenai informasi demografis responden, bagian kedua berisi daftar indikator-indikator kecurangan (red flags) oleh auditor. Bagian ketiga berisi langkah-langkah yang diperlukan sebagai upaya pencegahan kecurangan. Indikator-indikator yang digunakan sesuai dengan Statement of Auditing Standard No.99 yang diadaptasi dari penelitian Moyes (2006) dan Omar (2011), serta telah disesuaikan dengan kondisi di Indonesia. Indikator kecurangan dikelompokkan dalam empat dimensi sesuai The Fraud Diamond yaitu: (1) tekanan sebanyak 13 indikator, (2) kesempatan sebanyak 27 indikator, (3) rasionalisasi/sikap sebanyak 15 indikator, dan (4) kemampuan sebanyak 5 indikator. Total indikator yang digunakan adalah 60 indikator. Responden diminta memberi pendapat atas efektivitas red flags dalam mendeteksi kecurangan menggunakan empat skala poin yaitu 1 = Sangat Tidak Efektif, 2 = Tidak Efektif, 3 = Efektif, dan 4 = Sangat Efektif.

Bagian keempat berisi daftar langkah-langkah pencegahan kecurangan sesuai dengan SAS 99 Exhibit "Management Anti-Fraud Programs and Controls, Guidance to Help Prevent, Deter, and Detect Fraud". Terdapat 14 jenis tindakan yang dikelompokkan dalam tiga kategori utama yaitu menciptakan budaya kejujuran dan beretika yang tinggi, mengevaluasi proses dan pengendalian strategi anti fraud, dan mengembangkan proses pengawasan yang tepat. Responden diminta untuk mengidentifikasi efektivitas langkah-langkah pencegahan tersebut menggunakan empat skala poin yaitu 1 = Sangat Tidak Efektif, 2 = Tidak Efektif, 3 = Efektif, dan 4 = Sangat Efektif. Peneliti membandingkan efektivitas masing-masing kelompok red flags yang dikategorikan berdasarkan The Fraud Diamond. Penelitian ini menggunakan nilai ratarata (mean) keseluruhan untuk setiap kelompok red flags yang dinilai berdasarkan persepsi auditor internal. Selanjutnya setiap kelompok indikator akan dibuatkan peringkat dan disajikan 
berdasarkan Lima Besar Red Flags Berpredikat "Sangat Efektif" untuk kategori Pressure/Incentive, Opportunity, Rationalization, dan Capability.

Selain itu, penelitian ini juga menganalisis pengaruh karakteristik demografi auditor eksternal pada persepsi atas efektivitas red flags dalam mendeteksi kecurangan. Data dianalisis menggunakan regresi linear berganda, yang sebelumnya telah dilakukan pengujian asumsi klasik yaitu uji normalitas, uji multikolinearitas, dan uji heteroskedastisitas. Selanjutnya dilakukan uji kelayakan model meliputi uji determinasi $\left(R^{2}\right)$, uji F, dan uji t. Uji determinasi digunakan untuk mengukur kemampuan model dalam menerangkan variasi variabel dependen. Uji F digunakan untuk mengetahui pengaruh variabel bebas secara simultan terhadap variabel terikat, sedangkan uji t dilakukan untuk mengetahui pengaruh variabel bebas secara parsial terhadap variabel terikat (Ghozali 2011). Variabel bebas penelitian ini adalah karakteristik demografi responden yang diukur dengan gender, usia, tingkat pendidikan, masa kerja, pengalaman dalam mendeteksi kecurangan, serta pernah mengikuti pelatihan atau seminar, sementara variabel bebasnya adalah efektivitas red flags dalam mendeteksi kecurangan.

\section{HASIL DAN ANALISIS}

\subsection{Rincian Pengembalian Kuesioner}

Penelitian ini menggunakan data primer yang diperoleh dengan cara mendatangi secara langsung setiap BPR dan memberikan kuesioner sesuai dengan jumlah auditor internal yang ada pada BPR tersebut. Tenggang waktu yang diberikan untuk pengisian kuesioner adalah maksimal 60 hari sejak kuesioner diberikan untuk masing-masing responden. Jumlah kuesioner yang disebarkan sebanyak 101 kuesioner dengan tingkat pengembalian (response rate) sebesar 100\%. Dari 101 kuesioner yang telah kembali, terdapat 2 kuesioner yang tidak dapat digunakan dalam tahap analisis karena tidak semua item pernyataan terisi secara lengkap. Dengan demikian, jumlah kuesioner yang dapat diolah lebih lanjut adalah sebanyak 99 kuesioner.

\begin{tabular}{l|c|}
\multicolumn{2}{c}{ Tabel 1 } \\
\multicolumn{1}{c}{ Rincian Pengembalian Kuesioner } \\
\hline \multicolumn{1}{c|}{ Aktivitas } & Jumlah \\
\hline Jumlah kuesioner yang disebar & 101 \\
Kuesioner yang tidak kembali & - \\
Kuesioner yang dikembalikan & 101 \\
Tingkat pengembalian & $100 \%$ \\
Kuesioner yang tidak lengkap & 2 \\
Jumlah kuesioner yang dapat diolah & 99 \\
\hline Sumber: Data primer (diolah) & \\
\hline
\end{tabular}




\subsection{Karakteristik Responden}

Tahapan pertama dalam menganalisis kuesioner adalah melakukan identifikasi atas karakteristik auditor internal berdasarkan gender, usia, tingkat pendidikan, masa kerja, pengalaman dalam mendeteksi kecurangan, serta keikutsertaan auditor internal dalam pelatihan atau seminar mengenai pendeteksian kecurangan.

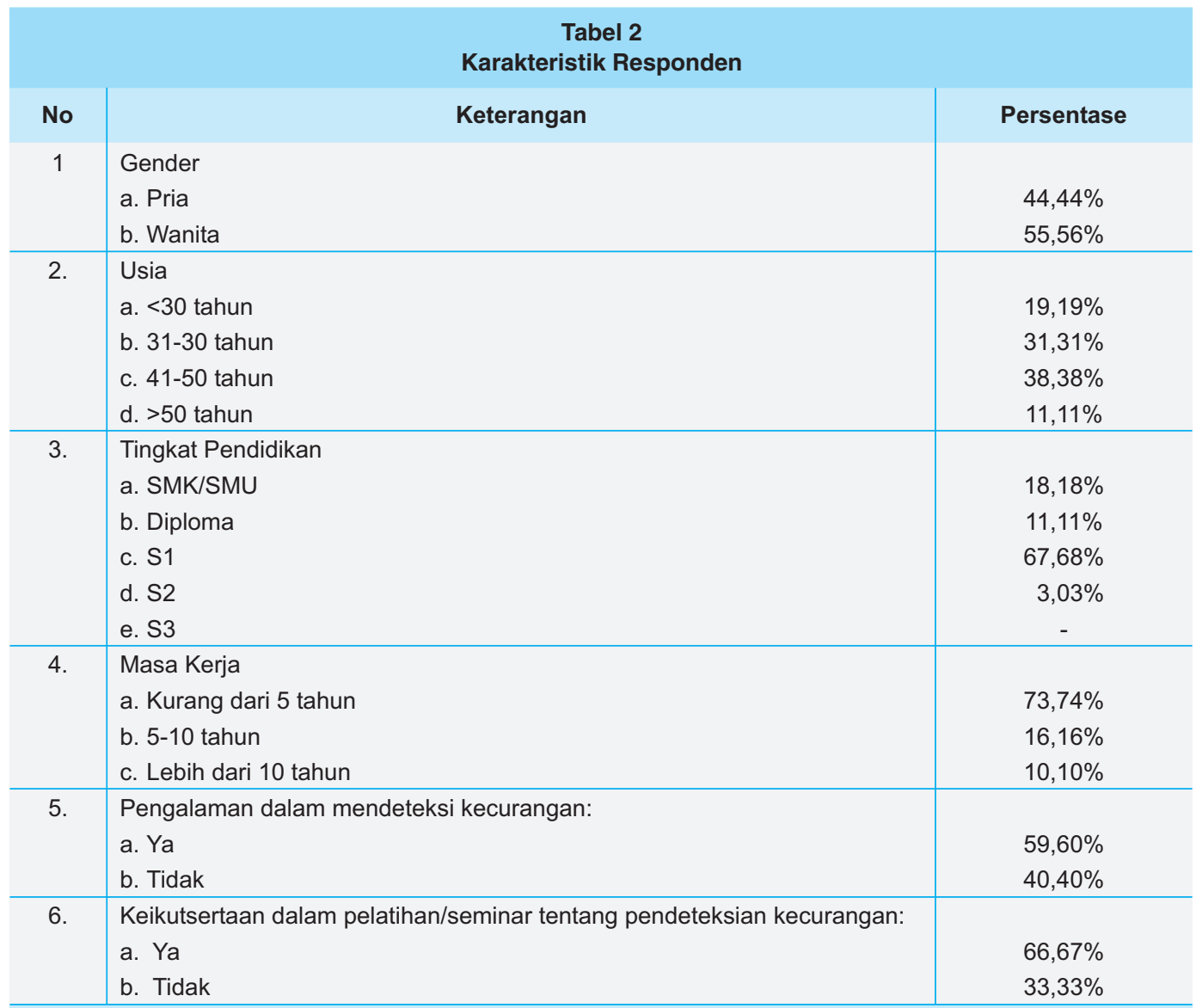

Sumber: Data primer (diolah)

\subsection{Persepsi atas Efektivitas Red Flags}

Tahapan selanjutnya adalah melakukan identifikasi atas persepsi auditor internal mengenai keefektifan penggunaan red flags dalam mendeteksi kecurangan laporan keuangan. Persepsi terkait dengan cara pandang individu terhadap fenomena yang terjadi di sekitarnya berdasarkan hasil pengamatan dan pengalaman sehingga setiap individu dapat memiliki persepsi yang sama ataupun berbeda (Yulifah dan Irianto, 2014). Penelitian ini bertujuan untuk mengidentifikasi 
efektivitas 60 indikator yang dikelompokkan menjadi empat kategori sesuai konsep "The Fraud Diamond". Responden mengidentifikasi peran indikator-indikator tersebut dalam empat kriteria jawaban yaitu "sangat tidak efektif", "tidak efektif", "efektif", dan "sangat efektif".

\begin{tabular}{|c|c|}
\hline \multicolumn{2}{|l|}{$\begin{array}{c}\text { Tabel } 3 \\
\text { Lima Besar Red Flags Berpredikat "Sangat Efektif" }\end{array}$} \\
\hline Uraian & Rata-rata \\
\hline \multicolumn{2}{|l|}{ Kategori: Tekanan/Insentif (Pressure/Incentive) ${ }^{1}$} \\
\hline 1. Adanya standar akuntansi, undang-undang, atau peraturan baru. & 3,73 \\
\hline 2. Manajemen dan/atau direksi sebagai pemangku kepentingan keuangan yang dominan dalam perusahaan. & 3,64 \\
\hline 3. Memiliki kemampuan lebih untuk melakukan kewajiban pemenuhan pembayaran utang. & 3,62 \\
\hline 4. Kerugian operasi perusahaan menyebabkan ancaman kebangkrutan, penyitaan, atau pengambilalihan aset perusahaan. & 3,51 \\
\hline 5. Kerentanan tinggi terhadap perubahan teknologi, keusangan produk keuangan, atau tingkat bunga. & 3,48 \\
\hline \multicolumn{2}{|l|}{ Kategori: Kesempatan (Opportunity)² } \\
\hline 1. Sistem pengendalian internal tidak memadai. & 3,42 \\
\hline 2. Terdapat transaksi yang material dengan pihak ketiga. & 3,42 \\
\hline 3. Dewan direksi kurang berfungsi dalam mengawasi proses pelaporan keuangan. & 3,39 \\
\hline 4. Kurangnya cuti wajib bagi karyawan. & 3,31 \\
\hline 5. Terdapat aktiva yang berukuran kecil tetapi bernilai tinggi. & 3,28 \\
\hline \multicolumn{2}{|l|}{ Kategori: Rasionalisasi (Rationalization) ${ }^{3}$} \\
\hline 1. Keinginan manajemen yang berlebihan untuk mempertahankan atau meningkatkan laba perusahaan. & 3,46 \\
\hline 2. Kegagalan manajemen untuk memperbaiki kondisi pelaporan secara tepat waktu. & 3,35 \\
\hline 3. Partisipasi berlebihan manajemen dalam pemilihan prinsip akuntansi atau dasar penentuan estimasi. & 3,27 \\
\hline 4. Perubahan perilaku atau gaya hidup manajemen. & 3,27 \\
\hline 5. Perilaku manajemen mendominasi dalam berurusan dengan auditor. & 3,26 \\
\hline \multicolumn{2}{|l|}{ Kategori: Kemampuan (Capability) $)^{4}$} \\
\hline 1. Seseorang memiliki posisi atau fungsi penting dalam organisasi. & 3,85 \\
\hline 2. Seseorang memiliki kemampuan untuk memahami dan mengeksploitasi kelemahan pengendalian internal. & 3,74 \\
\hline 3. Seseorang dengan kepribadian yang sangat persuasif (mampu mempengaruhi). & 3,47 \\
\hline 4. Seseorang memiliki ego yang kuat dan keyakinan besar. & 3,42 \\
\hline 5. Suatu kecurangan dapat dikatakan berhasil apabila secara efektif mampu menghindari pendeteksian kecurangan. & 3,38 \\
\hline \multicolumn{2}{|l|}{${ }^{1}$ Rata-rata kategori Tekanan sebesar 3,44} \\
\hline \multicolumn{2}{|l|}{${ }^{2}$ Rata-rata kategori Kesempatan sebesar 3,18 } \\
\hline \multicolumn{2}{|l|}{${ }^{3}$ Rata-rata kategori Sikap/Rasionalisasi sebesar 3,15 } \\
\hline${ }^{4}$ Rata-rata kategori Kemampuan sebesar 3,57 & \\
\hline
\end{tabular}




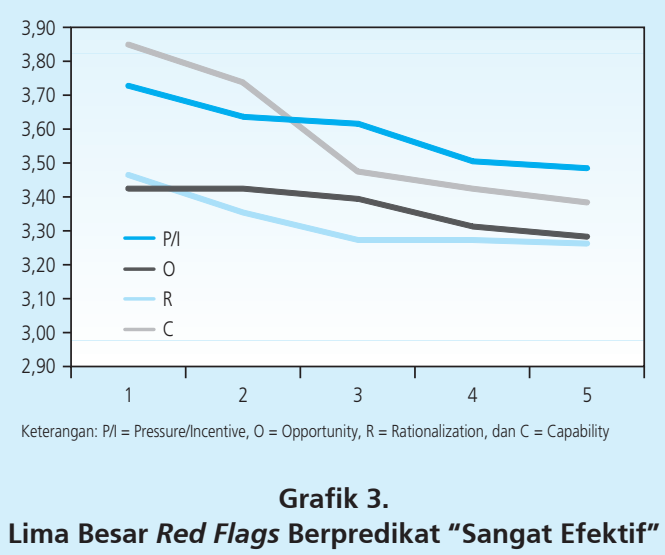

Berkenaan dengan level rata-rata untuk skor efektivitas, dapat disimpulkan bahwa indikator-indikator kecurangan (red flags) telah memenuhi kriteria efektif untuk digunakan dalam mendeteksi kecurangan. Hasil analisis atas jawaban responden menunjukkan bahwa dimensi The Fraud Diamond yang memiliki nilai rata-rata tertinggi adalah kemampuan (capability). Hasil penelitian ini mempertegas Theory of Fraud Diamond yang menekankan bahwa kemampuan seseorang memegang peranan penting ketika terjadinya fraud. Meskipun seseorang memiliki motivasi, peluang, dan rasionalisasi, namun apabila tidak memiliki kemampuan untuk melaksanakan atau menyembunyikan kecurangan tersebut maka kecurangan tidak mungkin terjadi. Apabila diibaratkan dengan sebuah pintu, kesempatan merupakan jalan untuk membuka pintu, selanjutnya tekanan (insentif) dan rasionalisasi yang membimbing seseorang menuju pintu tersebut, namun hanya kemampuan yang memungkinkan seseorang untuk mengenali pintu yang terbuka sebagai suatu kesempatan. Hal penting lainnya bahwa hanya orang-orang yang memiliki kapasitas tinggi yang dapat memahami dengan baik sistem pengendalian internal perusahaan, mengidentifikasi kelemahan, dan menggunakannya untuk suatu kecurangan. Seseorang harus memiliki keterampilan dan kemampuan ketika akan melakukan kecurangan. Jawaban responden dalam penelitian ini mendukung argumentasi Wolfe dan Hermanson (2004) yang menyatakan bahwa meskipun seseorang merasakan adanya tekanan, memiliki kesempatan dan rasionalisasi, namun fraud tidak mungkin terjadi tanpa kehadiran capability.

Apabila dibandingkan dengan hasil penelitian sebelumnya yang dilakukan oleh Moyes et al. (2006) untuk mengetahui persepsi auditor internal, hasil penelitian menunjukkan bahwa kategori Opportunity dan Rationalizations lebih efektif dalam mendeteksi kecurangan pelaporan keuangan dibandingkan kategori Pressures/Incentives. Penelitian selanjutnya yang dilakukan Yang et al. (2009) pada auditor eksternal dan auditor internal mengungkapkan bahwa indikator untuk kategori Pressures dan Opportunity lebih efektif dibandingkan dengan 
kategori Rationalizations, sementara penelitian Moyes et al. (2013) menyatakan bahwa kategori Opportunity paling efektif dibandingkan dua indikator lainnya.

Persepsi auditor internal dalam menentukan efektivitas red flags tentunya tidak terlepas dari pengaruh karakteristik demografi auditor internal tersebut. Karakteristik demografi seperti gender, usia, pendidikan, masa kerja, pengalaman mendeteksi kecurangan dalam suatu penugasan audit, serta kegiatan pelatihan seminar terkait dengan pendeteksian kecurangan yang pernah diikuti akan membentuk kompetensi auditor internal sehingga dapat melaksanakan tugas pendeteksian dengan tepat. Keterkaitan tersebut telah dibuktikan dengan hasil pengujian yang dilakukan menggunakan analisis regresi linear berganda seperti yang disajikan pada Tabel 4. Sebelumnya hasil penelitian ini telah memenuhi uji asumsi klasik sehingga dapat dilanjutkan pada uji regresi linear berganda.

\begin{tabular}{l|c|c|c|c}
\multicolumn{5}{c}{ Tasil Pengujian Pengaruh } \\
\multicolumn{1}{c}{ Karakteristik Demografi Auditor Internal pada Persepsi } \\
Variabel & B & t & Sig & Kesimpulan \\
(Constant) & 2.298 & .229 &, 000 & \\
\hline Gender & -.121 & .080 &, 134 & Tidak Berpengaruh \\
\hline Usia & -.055 & .041 &, 183 & Tidak Berpengaruh \\
\hline Pendidikan & .107 & .047 &, 024 & Berpengaruh \\
\hline Masa Kerja & .181 & .062 &, 004 & Berpengaruh \\
\hline Pengalaman & .302 & .085 &, 001 & Berpengaruh \\
\hline Pelatihan & .190 & .091 &, 040 & Berpengaruh \\
\hline R & .648 & & & \\
\hline R Square & .419 & & & \\
\hline Adjusted R2 & .382 & & & \\
\hline Sig F test & 0.00 & & & \\
\hline *Nilai signifikansi $<0.05$ & & & & \\
\hline
\end{tabular}

Tabel 4 menunjukkan nilai Adjusted R² sebesar 0.382 yang berarti bahwa sebesar $38.2 \%$ persepsi auditor internal dapat dijelaskan oleh karakteristik demografi seperti gender, usia, pendidikan, masa kerja, pengalaman dalam mendeteksi kecurangan, serta kegiatan pelatihan yang diikuti auditor internal, sementara sisanya sebesar $61.8 \%$ dijelaskan oleh variabel lain yang tidak dimasukkan dalam model penelitian ini. Hasil atas Uji Anova atau F test menyajikan nilai signifikansi sebesar 0.000 yang berarti bahwa semua karakteristik demografis tersebut berpengaruh secara simultan pada persepsi auditor internal. Hasil pengujian tersebut juga membuktikan bahwa persepsi auditor internal dipengaruhi oleh pendidikan, masa kerja, pengalaman mendeteksi kecurangan, maupun pelatihan yang diikuti. Meskipun demikian, dua karakteristik lain seperti gender dan usia tidak mempengaruhi persepsi auditor internal atas efektivitas red flags dalam mendeteksi kecurangan dalam dunia perbankan. 
Penelitian ini menunjukkan bahwa gender auditor internal tidak berpengaruh pada persepsi atas efektivitas red flags dalam mendeteksi kecurangan. Hasil penelitian ini menegaskan bahwa setiap auditor internal harus memiliki sikap konservatif, skeptis, dan investigatif untuk memastikan tidak terjadinya kecurangan dalam perusahaan. Hasil ini semakin menegaskan bahwa pria dan wanita memiliki kesetaraan tugas, tanggung jawab, dan kompetensi untuk mewujudkan BPR yang sehat. Fakta ini mendukung hasil penelitian Rustiarini dan Novitasari (2014) yang juga membuktikan bahwa perbedaan gender tidak berpengaruh pada persepsi auditor eksternal, namun bertolakbelakang dengan penelitian Moyes dan Baker (2009) yang menemukan bahwa auditor wanita lebih mungkin untuk mendeteksi kecurangan menggunakan red flags dibandingkan auditor pria. Demikian pula halnya dengan hasil pengujian usia auditor internal dan persepsi yang tidak menunjukkan adanya pengaruh yang signifikan. Untuk dapat menduduki posisi sebagai auditor internal, seseorang tentunya harus memiliki kompetensi yang diperlukan tanpa memperhitungkan usia. Meskipun individu memiliki usia yang sangat muda, namun apabila dipandang mampu untuk mengisi posisi ini, faktor usia tersebut akan diabaikan.

Karakteristik demografi masa kerja auditor internal berpengaruh pada persepsi atas efektivitas red flags, yang mendukung hasil penelitian Hegazy dan Kassem (2010) yang menemukan bahwa masa kerja auditor berpengaruh pada pendeteksian kecurangan menggunakan red flags. Semakin lama waktu seseorang memegang jabatan sebagai seorang auditor internal, tentunya akan semakin meningkat pengetahuan dan keahlian yang dimiliki. Masa kerja yang lama juga akan memberikan kesempatan bagi auditor internal untuk semakin dalam mengeksplorasi kemampuan diri untuk berprestasi, salah satunya meningkatkan kemampuan yang berkaitan dengan pendeteksian kecurangan. Masa kerja yang cukup lama juga akan memungkinkan auditor internal mengembangkan potensi diri melalui proses yang dimiliki. Apabila dikaitkan dengan persepsi auditor atas efektivitas red flags dalam mendeteksi kecurangan, semakin lama masa kerja auditor internal tentunya akan semakin efektif dalam mengindentifikasi red flags yang digunakan dalam mendeteksi kecurangan.

Seringkali tingkat pendidikan formal yang dimiliki seseorang digunakan sebagai ukuran tingkat pengetahuan yang dimiliki orang tersebut. Untuk dapat berprofesi sebagai seorang auditor internal, seseorang tentunya harus menempuh pendidikan yang terspesialisasi, khususnya dalam bidang akuntansi. Semakin tinggi pendidikan auditor maka semakin luas pengetahuan yang dimiliki sehingga akan mempengaruhi kemampuan dalam mengambil sutau keputusan, salah satunya berkaitan dengan penentuan efektivitas red flags dalam mendeteksi kecurangan. Auditor yang memiliki pendidikan magister akuntansi atau bisnis akan meningkatkan penggunaan red flags untuk mendeteksi kecurangan, dibandingkan auditor yang tidak memiliki gelar sama sekali (Moyes dan Baker, 2009). Hasil penelitian ini mendukung hasil penelitian Yang et al. (2009) dan Rustiarini dan Novitasari (2014) yang menunjukkan bahwa pendidikan auditor eksternal berpengaruh pada efektivitas pendeteksian kecurangan. 
Pengalaman yang dimaksudkan dalam penelitian ini adalah pengalaman mendeteksi kecurangan dalam penugasan sebelumnya. Berkaitan dengan karakteristik demografi pengalaman dalam mendeteksi kecurangan, hasil penelitian ini menunjukkan bahwa pengalaman merupakan variabel yang paling signifikan berpengaruh pada persepsi auditor internal atas efektivitas red flags. Auditor internal yang berpengalaman akan mampu mengenali pos-pos dalam laporan keuangan yang seringkali disalahgunakan, serta memiliki argumentasi yang akurat terhadap temuannya (Libby dan Frederick, 1990). Pengalaman yang dimiliki akan membantu auditor untuk menemukan metode pendeteksian yang tepat sebagai upaya untuk menciptakan sistem pengendalian internal yang memadai. Hasil penelitian ini mendukung hasil penelitian Rustiarini dan Novitasari (2014), serta Moyes dan Baker (2009) yang menemukan bahwa pengalaman dalam mendeteksi kecurangan mempengaruhi persepsi auditor atas efektivitas red flags dalam mendeteksi kecurangan.

Hasil pengujian terakhir untuk faktor demografi auditor internal menunjukkan bahwa keikutsertaan dalam pelatihan berpengaruh pada persepsi auditor atas efektivitas red flags. Kecurangan merupakan suatu hal yang tidak sering terjadi dalam perusahaan sehingga auditor internal akan jarang mendeteksi kecurangan dalam laporan keuangan. Untuk meningkatkan pengetahuan, auditor internal dapat mengikuti pelatihan formal yang dianggap memiliki kualitas setara dengan pengetahuan dari pengalaman sebelumnya. Tujuan pelatihan adalah meningkatkan fraud awareness atas potensi terjadinya kecurangan dalam perusahaan. Apabila auditor internal memiliki pengetahuan yang cukup dan fraud awareness yang tinggi, kepekaan atas munculnya gejala-gejala kecurangan akan membantu auditor internal mengidentifikasi efektivitas red flags yang tepat digunakan dalam prosedur pendeteksian kecurangan (Rustiarini dan Novitasari, 2014), serta memiliki kemampuan lebih tinggi dalam mendeteksi kecurangan daripada auditor yang tidak pernah mengikuti kegiatan tersebut (Yang et al., 2009; Moyes dan Baker, 2009). Beberapa penelitian sebelumnya mendukung pendapat bahwa pelatihan dapat membantu auditor internal untuk mengidentifikasi efektivitas red flags (Nieschwietz et al., 2000, Bierstaker et al., 2012).

\subsection{Tindakan Pencegahan Kecurangan}

Untuk dapat meminimalisasi terjadinya fraud, hendaknya upaya yang dilakukan BPR tidak hanya berupa pencegahan namun mengkombinasikan dengan upaya pendeteksian, penginvestigasian, dan perbaikan sistem untuk menciptakan strategi yang integral dalam mengendalikan kecurangan. Pencegahan merupakan pilar pertama dari strategi anti fraud yang bertujuan untuk menghentikan kecurangan yang terjadi. Terdapat 14 langkah-langkah pencegahan kecurangan yang dikelompokkan dalam tiga kategori utama yaitu menciptakan budaya kejujuran dan etika yang tinggi, mengevaluasi pelaksanaan dan pengendalian strategi anti fraud, dan mengembangkan proses pengawasan yang tepat (Sengur, 2012). 


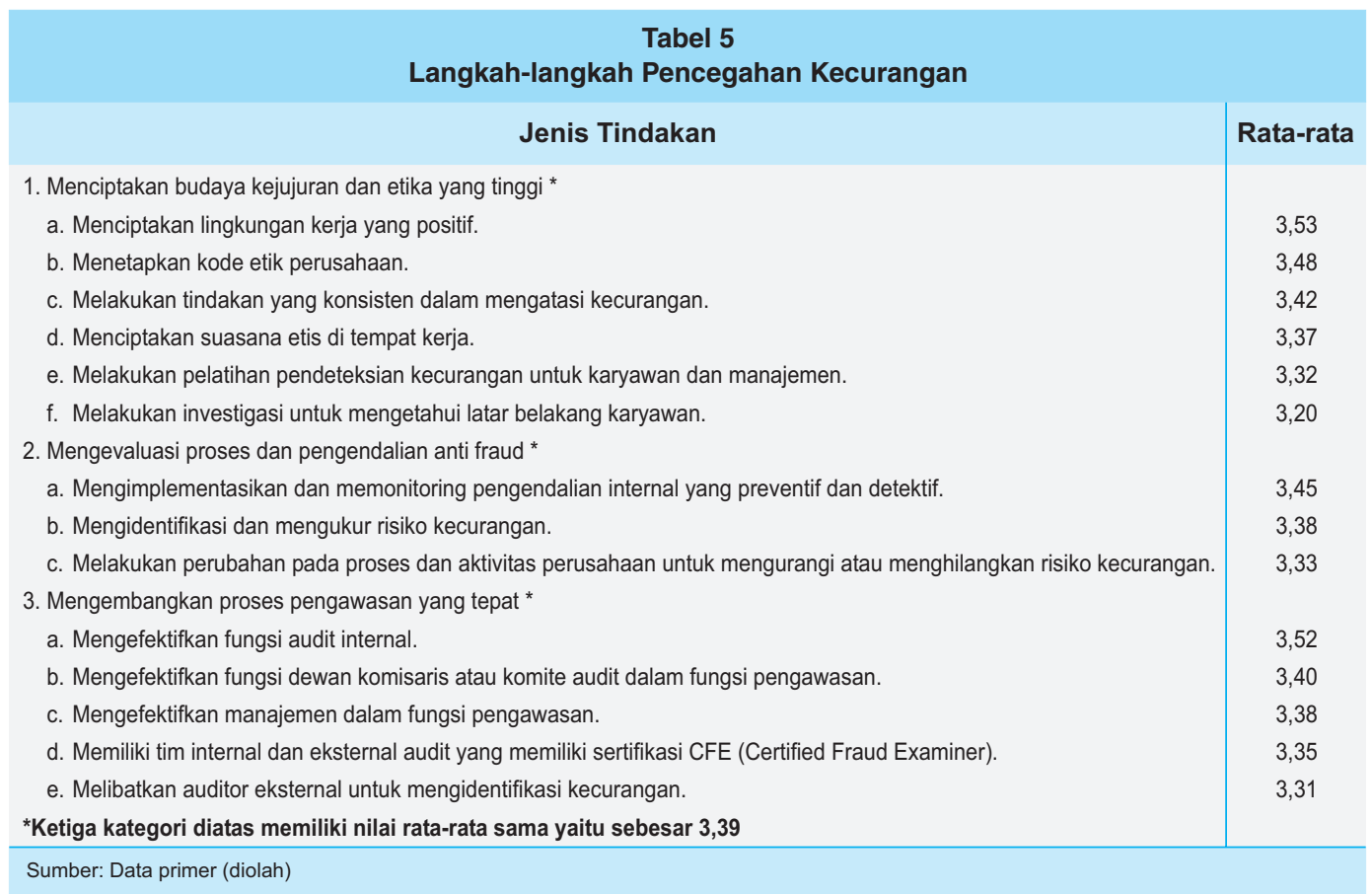

Langkah-langkah pencegahan pertama menekankan pada upaya untuk menciptakan budaya kejujuran dan etika yang tinggi. Terdapat enam komponen yang harus dipenuhi untuk memenuhi kondisi ini. Hasil analisis atas jawaban responden mengungkapkan bahwa hal terpenting yang harus diperhatikan adalah lingkungan kerja yang positif, dalam artian memperhatikan sistem promosi ataupun jenjang karir sehingga karyawan merasa aman dan dihargai dalam pekerjaan. Pimpinan juga agar senantiasa mengkomunikasikan pentingnya mematuhi kode etik perusahaan untuk mengurangi perilaku tidak etis, serta memberikan konsekuensi secara konsisten atas tindakan kecurangan yang dilakukan. Kondisi ini terwujud apabila pimpinan perusahaan dapat menciptakan suasana etis di tempat kerja. Apabila pimpinan telah memiliki integritas dan menjunjung tinggi nilai-nilai etika, maka karyawan pun tentu menegakkan nilai-nilai yang sama, begitupun sebaliknya. Dewan komisaris dan dewan direksi BPR juga wajib menumbuhkan budaya dan kepedulian anti fraud pada seluruh jajaran organisasi BPR.

Semua bentuk perilaku etis maupun tidak etis tersebut disosialisasikan melalui kegiatan pelatihan. Kegiatan ini bertujuan untuk meningkatkan kesadaran dan kemampuan karyawan dalam mengenali kecurangan yang terjadi, termasuk mengambil tindakan yang tepat ketika mengetahui orang lain melakukan tindakan yang tidak benar. Hal terpenting lainnya adalah perusahaan harus memiliki kebijakan yang efektif untuk meminimalkan kemungkinan memperkerjakan atau mempromosikan karyawan yang memiliki tingkat kejujuran rendah, khususnya untuk posisi vital dalam perusahaan. 
Upaya pencegahan kedua yang perlu diimplementasikan adalah melakukan evaluasi atas pelaksanaan proses dan pengendalian strategi anti fraud. Mengingat kecurangan yang terjadi pada BPR sebagian besar dilakukan oleh pihak internal perusahaan, maka BPR perlu memiliki sistem pengendalian intern yang andal untuk mendeteksi kemungkinan terjadinya kecurangan. Auditor internal perlu memonitoring sistem pengendalian internal perusahaan, mengidentifikasi proses, kontrol, dan prosedur lain yang diperlukan untuk mengurangi risiko yang teridentifikasi. Sistem pengendalian internal yang preventif dan detektif dapat berjalan secara efektif apabila manajemen telah mengidentifikasi dan mengukur aspek penilaian risiko kecurangan. Proses penilaian harus mempertimbangkan kerentanan perusahaan pada aktivitas kecurangan dan apakah hal tersebut menyebabkan salah saji material pada laporan keuangan atau kerugian yang material bagi perusahaan. Kegiatan lain yang mungkin dilakukan untuk mengurangi atau menghilangkan risiko kecurangan adalah membuat perubahan pada proses dan aktivitas perusahaan. Langkah ini diperlukan untuk mengurangi peluang pihak-pihak tertentu mempelajari sistem yang ada dan mencegah dilakukannya jenis kecurangan yang sama di masa yang akan datang.

Keberhasilan penerapan langkah-langkah pencegahan kecurangan sangat tergantung pada dukungan dan kebijakan beberapa pihak internal sebagai pengambil keputusan. Dalam rangka menguatkan sistem pengendalian internal, BPR wajib mengefektifkan peran auditor internal atau SPI. Fungsi ini bertugas dan bertanggungjawab untuk (1) membantu dewan direksi dan dewan komisaris dalam melakukan pengawasan operasional BPR; (2) membuat analisis dan penilaian di bidang keuangan, akuntansi dan operasional, dan kegiatan lain dengan cara pemeriksaan langsung dan analisis dokumen; (3) mengidentifikasi segala kemungkinan untuk memperbaiki dan meningkatkan efisiensi penggunaan sumber daya dan dana, dan (4) memberikan saran perbaikan dan informasi yang objektif tentang kegiatan yang diperiksa pada semua tingkatan manajemen. Apabila peran ini telah berfungsi dengan baik maka dapat meminimalkan potensi terjadinya risiko.

Peran pengawasan juga dilakukan oleh dewan komisaris dan komite audit. Komite audit membantu dewan komisaris memenuhi tanggung jawab pengawasannya pada proses pelaporan keuangan dan sistem pengendalian internal perbankan. Dewan direksi selaku manajemen BPR perlu mengawasi kegiatan pengendalian internal karena memiliki tanggung jawab untuk menyajikan laporan keuangan yang wajar. Manajemen wajib menindaklanjuti temuan audit dan rekomendasi dari satuan kerja atau pejabat yang bertanggungjawab atas pelaksanaan audit intern BPR, auditor ekstern, hasil pengawasan dewan komisaris, OJK, dan/atau otoritas lainnya. Dengan demikian manajemen ikut bertanggungjawab untuk melakukan upaya pencegahan dan pendeteksian kecurangan. Untuk dapat menerapkan prinsip akuntabilitas dan transparansi, BPR dapat melibatkan auditor eksternal dari suatu kantor akuntan publik untuk mengidentifikasi kecurangan. Tidak menutup kemungkinan pimpinan BPR memfasilitasi auditor internal untuk mengikuti sertifikasi yang berkaitan dengan CFE (Certified Fraud Examiner). Auditor yang 
memiliki sertifikat CFE dapat menjadi bagian dari tim auditor internal ataupun auditor eksternal sehingga dapat membantu dewan komisaris dan dewan direksi dalam aspek pengawasan.

\section{KESIMPULAN}

Kecurangan yang terjadi pada beberapa BPR perlu mendapatkan perhatian serius. Tidak jarang kondisi ini berakhir dengan likuidasi dan tentunya berdampak negatif pada pencitraan industri BPR. Menurunnya kepercayaan masyarakat terhadap bank ini juga dapat meluas ke bank-bank lainnya. Auditor internal sebagai bagian dari sistem pengendalian intern BPR menjadi harapan masyarakat untuk dapat mengungkapkan kecurangan yang terjadi. Fungsi audit intern harus dapat memastikan terwujudnya BPR yang sehat, berkembang secara wajar dan mampu memberikan pelayanan yang optimal kepada masyarakat.

Hasil dari studi ini menunjukkan bahwa indikator-indikator kecurangan (red flags) efektif digunakan dalam pendeteksian kecurangan. Dimensi the Fraud Diamond yang memiliki nilai rata-rata tertinggi adalah kemampuan (capability). Ini berarti kecurangan dapat terjadi apabila terdapat suatu tekanan, kesempatan, rasionalisasi, dan kemampuan dari pelaku kecurangan. Secara teoritis, hasil penelitian ini melengkapi keterbatasan hasil penelitian sebelumnya yang masih menggunakan konsep The Fraud Triangle.

Hasil pengujian atas karakteristik demografi auditor internal dipengaruhi oleh pendidikan, masa kerja, pengalaman mendeteksi kecurangan, maupun pelatihan yang diikuti, sementara gender dan usia tidak mempengaruhi persepsi auditor internal atas efektivitas red flags dalam mendeteksi kecurangan dalam dunia perbankan.

Selain mengidentifikasi keefektifan red flags dalam mendeteksi kecurangan, BPR juga melakukan upaya-upaya untuk melakukan pencegahan kecurangan. Terdapat tiga kelompok upaya yang dapat dilakukan yaitu menciptakan budaya kejujuran dan etika yang tinggi, mengevaluasi pelaksanaan dan pengendalian strategi anti fraud, dan mengembangkan proses pengawasan yang tepat.

Agar langkah-langkah pencegahan dapat berjalan secara efektif, para pimpinan puncak dalam manajemen BPR harus memahami dan mengenali berbagai risiko dalam melaksanakan kegiatan bisnisnya sehingga semua bagian yang terlibat dapat mengantisipasi sejak dini berbagai risiko yang ada. Sangat penting untuk memahami jenis faktor pencegahan yang diperlukan dalam lingkungan dimana kecurangan dilakukan.

Adanya pemahaman yang baik dari berbagai pihak tentunya akan mengoptimalkan upaya pencegahan kecurangan di BPR. Selain menggunakan red flags sebagai indikator-indikator kecurangan, manajemen BPR harus mengkombinasikan indikator ini dengan metode analisis lain seperti prediksi kegagalan perusahaan, analisis atas praktik akuntansi kreatif, dan model yang 
bisa memprediksikan perilaku karyawan. Hal ini untuk menjamin kesinambungan operasional BPR dalam jangka panjang, menjamin ketersediaan pelayanan jasa keuangan kepada UMKM dan masyarakat di pelosok daerah, serta untuk meningkatkan reputasi dan kepercayaan masyarakat terhadap BPR. 


\section{DAFTAR PUSTAKA}

American Institute of Certified Public Accountant's. (2002). Consideration of Fraud in A Financial Statement Audit. Statement on Auditing Standards. No. 99. New York.

Association of Certified Fraud Examiners. (2010). Report to The Nation on Occupational Fraud. https://acfe.com/ documents/2010RttN.pdf, diunduh pada 5 Oktober 2016.

Albrecht, S., K. Howe dan M. Romney. (1986). Red-Flagging Management: a Validation. Advances in Accounting: 323-333.

Apostolou B, Hassell J, Webber S, dan Sumners G. (2001). The Relative Importance of Management Fraud Risk Factors. Behavioral Research in Accounting, 13: 1-24.

Bank Indonesia. (2016). Kajian Ekonomi dan Keuangan Regional Triwulan II 2016. http:// www.bi.go.id/id/publikasi/kajian-ekonomi-regional/bali/Pages/Kajian-Ekonomi-danKeuanganRegional-Provinsi-Bali-Agustus-2016.aspx diunduh pada 1 Desember 2016.

Bank Indonesia. (2016). Surat Edaran Bank Indonesia No.13/28/DPNP tentang Penerapan Strategi Anti Fraud bagi Bank Umum.

Bierstaker, J.L., J. E. Huntn, dan J. C Thibodeau. (2012). Does Fraud Training Help Auditors Identify Fraud Risk Factors? Advances in Accounting Behavioral Research, 15: 85-100.

Blokdijk H., Drieenhuizen F, Simunic DA, dan Stein MT. (2003). Factors Affecting Auditors' Assessments of Planning Materiality. Auditing: A Journal of Practice \& Theory, 22 (2): 297-307.

Choo, F. dan Tan, K. (2007). An "American Dream" Theory of Corporate Executive Fraud. Accounting Forum, 31 (2): 203-215.

Coram P, Ferguson C, dan Moroney R. (2008). Internal Audit, Alternative Internal Audit Structures and the Level of Misappropriation of Assets Fraud. Accounting \& Finance, 4: 543-59.

Cressey, D. R. (1950). The Criminal Violation of Financial Trust. American Sociological Review, 15 (6): 738-743.

Cressey, D. R. (1953). Other People's Money; A Study of the Social Psychology of Embezzlement. New York, NY: Free Press.

Friedman, S. (1995). Case Study: Pay Attention to Warning Signals. Journal of Accountancy: 65-80.

Ghozali, Imam. (2011). Aplikasi Analisis Multivariate Dengan Program IBM. SPSS 19 (Edisi Kelima) Semarang: Universitas Diponegoro. 
Gillentine, A. (2009). Business Fraud on the Rise During Recession. The Colorado Springs Business Journal. http://csbj.com/2009/12/17/business-fraud-on-the-rise-during-recession diunduh pada 5 Oktober 2016.

Gulllkvist, B dan A. Jokippi. (2013). Perceived Importance of Red Flags Across Fraud Types. Critical Perspectives on Accounting, 24: 44-61.

Groveman, H. (1995). How Auditors can Detect Financial Statements Misstatement. Journal of Accountancy: 83-86.

Hay, L. (2013). The Changing Profile of Fraud. http://www.ohioscpa.com/mobile/currentnews/2013/03/13/the-changing-profile-offraud?c=1 diunduh pada 5 Oktober 2016

Hegazy, Mohamed dan Kassem, Rasha. (2010). Fraudulent Financial Reporting: Do Red Flags Really Help? International Journal of Academic Research: Economics and Engineering, 4: $69-79$.

Heiman-Hoffman, Vicky B, Kimberly P. Morgan dan James M Patton, (1996). The Warning Signs of Fraudulent Financial Reporting. Journal of Accountancy, 182 (4).

Kaplan, S. dan Reckers, P. M. J. (1995). Auditors' Reporting Decisions for Accounting Estimates: The Effect of Assessments of The Risk of Fraudulent Financial Reporting, Managerial Auditing Journal, 10 (5): 27-36.

KPMG. (2009). Fraud Survey 2009. http://www.kpmg.com/ZA/en/IssuesandInsights/ ArticlesPublications/Risk-Compliance/Pages/Fraud-Survey-2009.aspx. diunduh pada 5 Oktober 2016.

Koornhof, C. dan Plessis, D Du. (2000). Red Flagging as an Indicator of Financial Statement Fraud: The Perspective of Investors and Lenders. Meditari Accountancy Research, 8: 69-93.

Libby, R. dan D.M. Frederick. (1990). Experience and The Ability to Explain Audit Findings. Journal of Accounting Research, 28 (2): 348-367.

Liou F-M. (2008). Fraudulent Financial Reporting Detection and Business Failure Prediction Models: A Comparison. Managerial Auditing Journal, 7: 650-62.

Messier Jr WF, Martinov-Bennie N, dan Eilifsen A. A (2005). Review and Investigation of Empirical Research on Materiality: Two Decades Later. Auditing: A Journal of Practice \& Theory, 2:153-87.

Moeller. (2009). Brink's Modern Internal Auditing, $7^{\text {th }}$ Edition. New Jersey: John Wiley \& Sons. Moyes, Glen D., Ping Lin, Raymond M. Landry, dan Handan Vicdan. (2006). Red Flags Detecting Fraud. Journal of Accounting, Ethics \& Public Policy, 6 (1): 1-28. 
Moyes, Glen D. (2007). The Differences in Perceived Level of Fraud-Detecting Effectiveness of SAS No. 99 Red Flags Between External and Auditor Internals. Journal of Business \& Economics Research. 6: 9-25.

Moyes, G.D. dan C. R. Baker. (2009). Factors Inflencing The Use of Red Flags to Detect Fraudulent Financial Reporting, Internal Auditing, 24 (3): 33-40.

Moyes, Glen D., Mohamed Din, dan Hesri Faizal. (2013). Malaysian Internal and External Auditor Perceptions of the Effectiveness of Red Flags for Detecting Fraud. International Journal of Auditing Technology, 1 (1): 91-106.

Nieschwietz, R. J., Schultz, J. J., dan Zimbelman, M. F. (2000). Empirical Research on External Auditors' Detection of Financial Statement Fraud. Journal of Accounting Literature, 19: 190-246.

Norman C, Rose J, dan Suh I. (2011) The Effects of Disclosure Type and Audit Committee Expertise on Chief Audit Executives' Tolerance for Financial Misstatements. Accounting, Organizations and Society, 36:102-8.

Omar, Normah Binti. (2011). Fraud Diamond Risk Indicator: an Assessment of Its Importance and Usage. http://www.researhgate.net/publication diunduh pada 5 Oktober 2016.

Omar, Normah Binti Omar, dan H. F. Mohamad Din. (2010). Fraud Diamond Risk Indicator: An Assessment of Its Importance and Usage. http://ieeexplore.ieee.org/ document/5773853/ diunduh pada 5 Oktober 2016.

Otoritas Jasa Keuangan. (2015). Peraturan Otoritas Jasa Keuangan No 4/POJK.03/2015 tentang Penerapan Tata Kelola bagi Bank Perkreditan Rakyat.

Otoritas Jasa Keuangan. (2016). Surat Edaran Otoritas Jasa Keuangan No 7/SEOJK.03/2016 tentang Standar Pelaksanaan Fungsi Audit Intern Bank Perkreditan Rakyat.

Otoritas Jasa Keuangan. (2016). Laporan Profil Industri Perbankan Triwulan I-2016.

Pincus, Karen V. (1989). The Efficacy of A Red Flags Questionnaire for Assessing The Possibility of Fraud. Accounting, Organizations and Society, 12 (1-2): 153-163.

PriceWater House Coopers. (2009). The Global Economic Crime Survey: Economic Crime in A Downturn

PriceWater House Coopers (2004). The Emerging Role of Internal Audit in Mitigating Fraud and Reputation Risk.

Radar Bali Jawa Pos. (2016). Kondisi Tak Pasti, Kecurangan Belum Berhenti. Edisi Minggu 27 November 2016, halaman 21.

Robbins, Stephen A., dan Judge, Timothy. (2008). Perilaku Organisasi 2 Edisi 12. Jakarta: Salemba Empat. 
Rustiarini, Ni Wayan dan Ni Luh Gde Novitasari. (2014). Persepsi Auditor atas Efektivitas Red Flags untuk Mendeteksi Kecurangan Pelaporan Keuangan. Jurnal Akuntansi Multiparadigma, 05 (3): 345-354.

Rustendi, T. (2009). Analisis terhadap Faktor Pemicu Terjadinya Fraud (Suatu Kajian Teoritis bagi Kepentingan Audit Internal). Jurnal Akuntansi, 9 (2): 705-714.

Sengur, Evren Dilek. (2012). Auditors' Perception of Fraud Prevention Measures: Evidence from Turkey. Annales Universitatis Apulensis Series Oeconomica, 14 (1): 128-138.

Tuanakotta, Theodorus M. (2010). Akuntansi Forensik dan Audit Investigatif. Edisi 2. Jakarta: Salemba Empat.

Wolfe, David T. dan D. R. Hermanson. (2004). The Fraud Diamond: Considering The Four Elements of Fraud. The Certified Public Accountants (CPA) Journal. December: 38-42.

Weisenborn, D. dan Norris, D.M. (1997). Red Flags of Management Fraud, National Public Accountant, 42 (2): 29-33.

Yang, Weifang, Moyes, Glen D., Hamedian, Hamed, dan Rahradian, Azar. (2010). Professional Demographic Factors That Influence Iranian Auditors' Perceptions of the Fraud-Detecting Effectiveness of Red Flags. International Business \& Economics Research Journal, 9 (1): 83-102.

Yulifah, Anna dan Gugus Irianto. (2014). Persepsi Auditor Eksternal tentang Determinan Pencegahan Kecurangan Laporan Keuangan. Jurnal IImiah Mahasiswa FEB Universitas Brawijaya, 2 (2) http://portalgaruda.org diunduh pada 5 Oktober 2016.

http://beritadewata.com/Ekonomi-dan-Bisnis/Badung/OJK-Gelar-Diskusi-Ditengah-KetatnyaPersaingan-BPR.htm/ diunduh 17 November 2016

http://bali.bisnis.com/read/20151215/14/56043/kinerja-bpr-di-bali-kredit-tumbuh-125 diunduh

17 November 2016

http://bisniskeuangan.kompas.com/read/2016/06/09/204422226/tahun.2005.sampai.2016. Ips.likuidasi.71.bank diunduh 22 September 2016.

http://bali.tribunnews.com/2016/05/11/kredit-macet-bpr-di-bali-capai-427-persen-ini-saran-ojk diunduh 17 November 2016

http://finansial.bisnis.com/read/20110513/90/30259/hampir-70-percent-bpr-tutup-karena-fraud diunduh 22 September 2016.

https://finance.detik.com/moneter/d-3344651/bpr-paling-banyak-lakukan-pidana-perbankanini-sebabnya diunduh 17 November 2016 http://infobanknews.com/bpr-ditutup-lagi-lagi-karena-fraud/ diunduh 22 September 2016. 


\section{LAMPIRAN 1}

\begin{tabular}{|c|c|c|}
\hline No & Indikator & Mean \\
\hline 1 & Adanya standar akuntansi, undang-undang, atau peraturan baru $(\mathrm{P} / \mathrm{l})$ & 3,73 \\
\hline 2 & Manajemen/dan atau direksi sebagai pemangku kepentingan keuangan yang dominan dalam perusahaan (P/I) & 3,64 \\
\hline 3 & Memiliki kemampuan lebih untuk melakukan kewajiban pemenuhan pembayaran utang $(\mathrm{P} / \mathrm{I})$ & 3,62 \\
\hline 4 & $\begin{array}{l}\text { Kerugian operasi perusahaan menyebabkan ancaman kebangkrutan, penyitaan, atau pengambilalihan aset } \\
\text { perusahaan (P/I) }\end{array}$ & 3,51 \\
\hline 5 & Kerentanan tinggi terhadap perubahan teknologi, keusangan produk keuangan, atau tingkat bunga (P/I) & 3,48 \\
\hline 6 & Dampak nyata yang dirasakan akibat pelaporan hasil keuangan yang buruk $(\mathrm{P} / \mathrm{I})$ & 3,48 \\
\hline 7 & $\begin{array}{l}\text { Pertumbuhan laba cepat dan tidak biasa, terutama bila dibandingkan dengan perusahaan lain dalam industri } \\
\text { yang sama (P/I) }\end{array}$ & 3,45 \\
\hline 8 & Tingkat kompetisi tinggi, adanya kejenuhan pasar, disertai dengan penurunan laba (P/I) & 3,40 \\
\hline 9 & Adanya bagian signifikan dari kompensasi bonus dan dividen $(\mathrm{P} / \mathrm{l})$ & 3,39 \\
\hline 10 & $\begin{array}{l}\text { Penurunan jumlah nasabah dana pihak ketiga, meningkatnya risiko kredit atau perekonomian secara } \\
\text { keseluruhan }(\mathrm{P} / \mathrm{l})\end{array}$ & 3,34 \\
\hline 11 & Tingkat pertumbuhan laba tidak realistis atau tren ekspektasi manajemen yang disampaikan terlalu optimis $(\mathrm{P} / \mathrm{l})$ & 3,30 \\
\hline 12 & Manajemen dan/atau dewan direksi secara pribadi bersedia menjamin hutang perusahaan yang material $(\mathrm{P} / \mathrm{l})$ & 3,27 \\
\hline 13 & $\begin{array}{l}\text { Berulang kali memperoleh arus kas negatif atau tidak mampu menghasilkan arus kas positif ketika } \\
\text { melaporkan laba (P/I) }\end{array}$ & 3,09 \\
\hline 14 & Sistem pengendalian internal tidak memadai $(\mathrm{O})$ & 3,42 \\
\hline 15 & Terdapat transaksi dengan pihak ketiga yang material $(\mathrm{O})$ & 3,42 \\
\hline 16 & Dewan direksi kurang berfungsi dalam mengawasi proses pelaporan keuangan $(0)$ & 3,39 \\
\hline 17 & Kurangnya cuti wajib bagi karyawan $(0)$ & 3,31 \\
\hline 18 & Terdapat aktiva yang berukuran kecil tetapi bernilai tinggi $(0)$ & 3,28 \\
\hline 19 & Terdapat persediaan yang berukuran kecil $(\mathrm{O})$ & 3,26 \\
\hline 20 & Kesulitan menentukan individu yang memiliki hak pengendalian dalam perusahaan $(0)$ & 3,24 \\
\hline 21 & $\begin{array}{l}\text { Adanya posisi keuangan yang kuat untuk mendominasi sektor keuangan yang memungkinkan perusahaan } \\
\text { mengatur syarat/ ketentuan sehingga mengakibatkan transaksi yang tidak pantas }(O)\end{array}$ & 3,22 \\
\hline 22 & Tingginya perputaran tenaga kerja bidang akuntansi, internal audit, atau staf teknologi informasi $(\mathrm{O})$ & 3,19 \\
\hline 23 & Tidak memadainya prosedur perekrutan tenaga kerja $(\mathrm{O})$ & 3,19 \\
\hline 24 & Rekonsiliasi aset kurang lengkap dan tepat waktu (O) & 3,18 \\
\hline 25 & Tidak memadainya pemahaman manajemen tentang teknologi informasi $(\mathrm{O})$ & 3,18 \\
\hline 26 & Aset, kewajiban, pendapatan, beban dinilai berdasarkan estimasi yang tidak realistis $(0)$ & 3,17 \\
\hline 27 & Tidak memadainya akses pengendalian atas catatan terkomputerisasi $(0)$ & 3,16 \\
\hline 28 & Tidak memadainya keamanan fisik atas aset $(\mathrm{O})$ & 3,15 \\
\hline 29 & Terdapat transaksi yang material, tidak biasa, atau memiliki kompleksitas tinggi $(\mathrm{O})$ & 3,14 \\
\hline
\end{tabular}




\begin{tabular}{|c|c|c|}
\hline No & Indikator & Mean \\
\hline 30 & Tidak memadainya sistem pengawasan manajemen $(\mathrm{O})$ & 3,14 \\
\hline 31 & Tersedia kas dalam jumlah besar (O) & 3,13 \\
\hline 32 & Tidak memadainya kepatuhan pencatatan atas aset $(0)$ & 3,11 \\
\hline 33 & Tidak memadainya pembagian tugas dan prosedur pemeriksaan yang independen $(0)$ & 3,10 \\
\hline 34 & Tidak memadainya sistem otorisasi dan persetujuan transaksi $(0)$ & 3,09 \\
\hline 35 & Tingginya pergantian dewan direksi $(0)$ & 3,07 \\
\hline 36 & Struktur organisasi terlalu rumit $(\mathrm{O})$ & 3,05 \\
\hline 37 & Tidak terdapat sistem akuntansi dan informasi yang memadai $(0)$ & 3,05 \\
\hline 38 & Transaksi tidak dicatat tepat waktu dan tidak terdokumentasi dengan baik $(\mathrm{O})$ & 3,05 \\
\hline 39 & Terdapat aset yang mudah dibawa (emas, chip komputer) $(0)$ & 3,03 \\
\hline 40 & Manajemen didominasi oleh satu orang atau satu kelompok kecil dalam perusahaan tanpa kontrol yang jelas (O) & 2,97 \\
\hline 41 & Keinginan manajemen yang berlebihan untuk mempertahankan atau meningkatkan laba perusahaan $(R)$ & 3,46 \\
\hline 42 & Kegagalan manajemen untuk memperbaiki kondisi pelaporan secara tepat waktu $(R)$ & 3,35 \\
\hline 43 & Partisipasi berlebihan manajemen dalam pemilihan prinsip akuntansi atau dasar penentuan estimasi $(R)$ & 3,27 \\
\hline 44 & Perubahan perilaku atau gaya hidup manajemen $(R)$ & 3,27 \\
\hline 45 & Perilaku manajemen mendominasi dalam berurusan dengan auditor $(R)$ & 3,26 \\
\hline 46 & Komitmen manajemen kepada pihak ketiga untuk mencapai estimasi yang tidak realistis $(R)$ & 3,25 \\
\hline 47 & Manajemen melakukan pembatasan formal atau informal pada auditor $(\mathrm{R})$ & 3,14 \\
\hline 48 & Manajemen menunjukkan perilaku ketidaksenangan atau ketidakpuasan atas kinerja perusahaan (R) & 3,12 \\
\hline 49 & $\begin{array}{l}\text { Sering terjadi perselisihan dengan auditor eksternal terdahulu terkait dengan akuntansi, audit, atau masalah } \\
\text { pelaporan keuangan }(\mathrm{R})\end{array}$ & 3,07 \\
\hline 50 & $\begin{array}{l}\text { Manajemen berupaya membenarkan selisih atau menggunakan standar akuntansi yang tidak pantas untuk } \\
\text { dasar materialitas }(\mathrm{R})\end{array}$ & 3,03 \\
\hline 51 & Manajemen mengabaikan kebutuhan untuk memantau atau mengurangi risiko $(R)$ & 3,02 \\
\hline 52 & Memiliki sejarah pelanggaran hukum atau terlibat dalam kecurangan atau pelanggaran hukum $(R)$ & 3,01 \\
\hline 53 & $\begin{array}{l}\text { Manajemen memberikan tuntutan tidak masuk akal pada auditor untuk menyelesaikan audit atau menerbitkan } \\
\text { laporan auditor dalam waktu yang singkat (R) }\end{array}$ & 3,00 \\
\hline 54 & Manajemen mengabaikan pengendalian internal atas penyalahgunaan aset $(R)$ & 3,00 \\
\hline 55 & $\begin{array}{l}\text { Manajemen menggunakan cara tidak legal untuk meminimalkan laba yang dilaporkan dengan alasan } \\
\text { mengurangi pembayaran pajak (R) }\end{array}$ & 2,99 \\
\hline 56 & Seseorang memiliki posisi atau fungsi penting dalam organisasi (C) & 3,85 \\
\hline 57 & Seseorang memiliki kemampuan untuk memahami dan mengeksploitasi kelemahan pengendalian internal (C) & 3,74 \\
\hline 58 & Seseorang dengan kepribadian yang sangat persuasif (mampu mempengaruhi) (C) & 3,47 \\
\hline 59 & Seseorang memiliki ego yang kuat dan keyakinan besar (C) & 3,42 \\
\hline 60 & $\begin{array}{l}\text { Suatu kecurangan dapat dikatakan berhasil apabila secara efektif mampu menghindari pendeteksian } \\
\text { kecurangan (C) }\end{array}$ & 3,38 \\
\hline
\end{tabular}

